\title{
Emissions control catalysts: Links between Fecralloy preoxidation and coating adherence
}

\author{
Stephen A. Adegbite \\ School of Chemical Engineering, University of Birmingham, Edgbaston, Birmingham B15 2TT, United Kingdom. \\ E-mail: stephen_adegbite@hotmail.com.Tel: +44(0)1216045143. \\ Accepted 29 September, 2011
}

\begin{abstract}
Tightening emissions legislation for vehicles across the world has caused the use of monolith catalysts in automobile emission control to become ubiquitous. In this study, the physiochemical transformations caused by thermal pre-oxidation of the surface of Fecralloy ${ }^{\circledR}$ foil, an integral component of emissions control catalysts, have been studied to assess their role on coating film adherence. The foil coupons were pre-oxidised at $950^{\circ} \mathrm{C}$ for $0,5,10$ and $30 \mathrm{~h}$ and the mass gain was found to fit a simplified hyperbolic model. Measurements were made of surface topography and microstructure using laser profiling interferometry (LPI) and scanning electron microscopy (SEM), with phase analysis being obtained from X-ray diffraction (XRD). The optimal surface roughness was obtained after $10 \mathrm{~h}$ of pre-oxidation, when the surface contained significant amounts of $\alpha$-alumina arranged as randomly oriented whiskers. Upon coating of the treated foil coupons with y-alumina slurry, the sample pre-oxidised for $10 \mathrm{~h}$ gave the best performance in terms of coating film loading of 7.94 mass \% and adherence of less than 10 mass \% loss.
\end{abstract}

Key words: Catalyst, Fecralloy ${ }^{\circledR}$, pre-oxidation, alumina, coating, adherence.

\section{INTRODUCTION}

Tightening emissions legislation for vehicles across the world has caused the use of monolith catalysts in automobile emission control to become ubiquitous. Their impact has been considerable, with emission levels from exhaust systems of passenger cars falling by more than $90 \%$ since 1975 , and with zero emissions now a future target. Environmentally harmful carbon monoxide and oxides of nitrogen in the exhaust stream are converted inside the monolith catalyst into carbon dioxide and nitrogen (Acres and Harrison, 2004; Twigg, 2006).

Monoliths are structures comprised of multiple parallel channels. One method of producing monolith catalysts is to coat the monolith surfaces with $Y$-alumina film containing active species (usually platinum group metals, PGMs, such as $\mathrm{Pt}, \mathrm{Pd}$ and $\mathrm{Rh}$ ). Monoliths are generally made from either metallic or ceramic materials, the former from thin metal sheet such as Fecralloy ${ }^{\circledR}$, the focus of this study, and the latter typically from cordierite (Avila et al., 2005). Fecralloy ${ }^{\circledR}$ is comprised essentially of iron, $\mathrm{Fe}$, chromium, $\mathrm{Cr}$, and aluminium, Al. It is well suited for catalyst support applications because of its high mechanical strength, thermal conductivity and ductility which make it easy to process. It clearly outperforms cordierite as a monolith material in all these crucial properties (Hickman and Schmidt, 1992b; 1992a).

To ensure adherence of the $Y$-alumina coatings, Fecralloy ${ }^{\circledR}$ has to be pre-oxidised which changes its surface topography to provide a rough surface (Cybulski and Moulijn, 2006). Pre-oxidation also provides enrichment of the Fecralloy ${ }^{\circledR}$ surface with aluminium, therefore prolonging the product component life (Nicholls and Quadakkers, 2002). Some studies have assessed the effects of pre-oxidation on dip-coated foil coupons, by relating the surface microstructure obtained by scanning electron microscopy (SEM) to the coating adherence(Jia et al., 2007; Zhao et al., 2003). However, these comparisons are somewhat qualitative in nature and do not consider a quantitative measure of the surface roughness, nor do they address coating at a controlled shear rate. In this new study, a detailed assessment of Fecralloy ${ }^{\circledR}$ two-dimensional (2D) and three-dimensional (3D) surface topography by laser profiling interferometry (LPI) was performed as a function of pre-oxidation conditions. In addition, SEM and X-ray diffraction (XRD) 

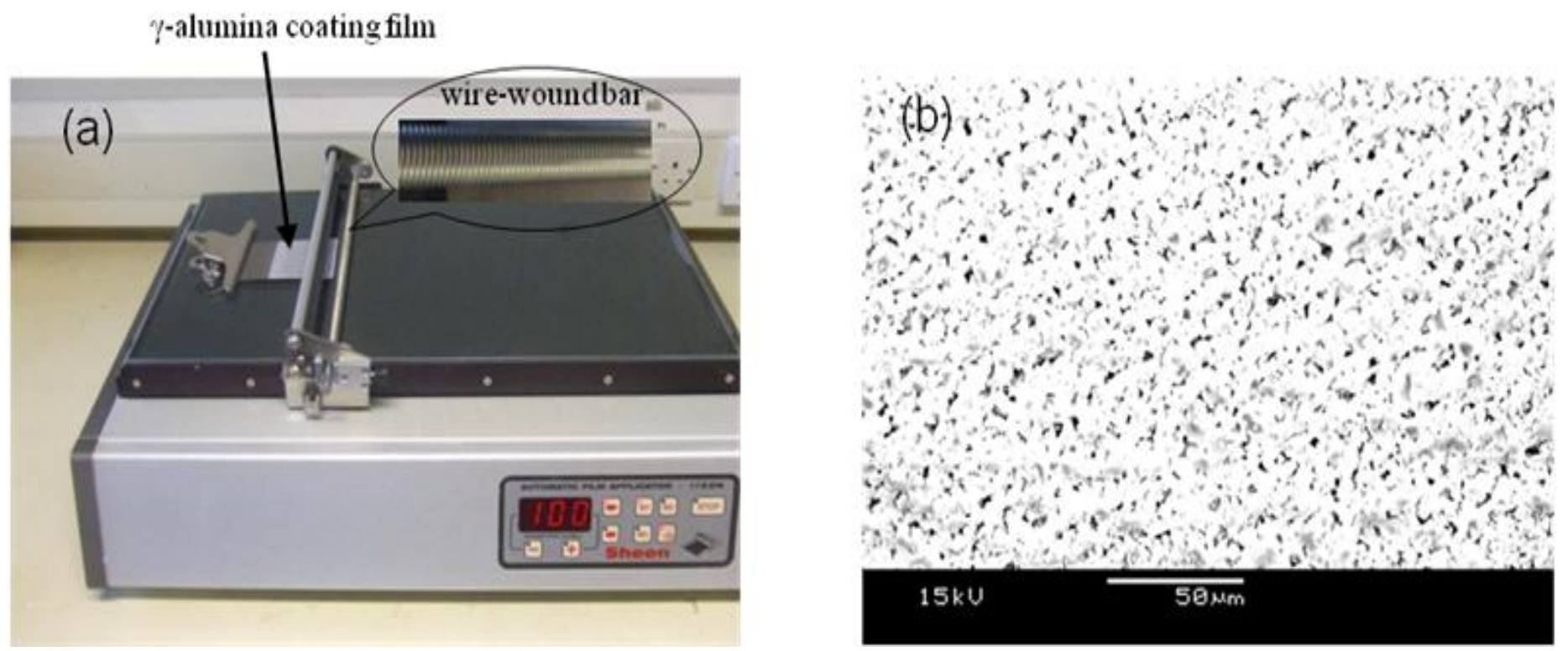

Figure 1. Coating of Fecralloy ${ }^{\circledR}$ supports: (a) $\mathrm{Y}$-alumina coating film applied by $1132 \mathrm{~N}$ applicator; (b) SEM micrograph of coating surface.

techniques have been applied to give a comprehensive description of the physiochemical transformations caused by pre-oxidation. To determine the effect of pre-oxidation on coating film adherence, $y$-alumina slurry was deposited onto the Fecralloy ${ }^{\circledR}$ foil coupons at a controlled shear rate using an automatic film applicator, and the resulting composites were dried and calcined afterwards. The coating film loading and adherence were determined to reveal the optimal pre-oxidation conditions.

\section{MATERIALS AND METHODS}

\section{Pre-treatment and assessment of Fecralloy ${ }^{\circledR}$ foil}

Commercially available Fecralloy ${ }^{\circledR}$ foil (GoodFellow, UK) of $50 \mu \mathrm{m}$ thickness with a composition of $\mathrm{Fe}(72.6$ wt \%), $\mathrm{Cr}(22.0 \mathrm{wt} \%), \mathrm{Al}$ $(4.80 \mathrm{wt} \%), \mathrm{Y}(0.30 \mathrm{wt} \%)$ and $\mathrm{Si}(0.30 \mathrm{wt} \%)$ was used. The asreceived foil was cut into $50 \mathrm{~mm} \times 80 \mathrm{~mm}$ coupons without any prior mechanical polishing. The pre-treatment of the coupons consisted of the following steps (Jia et al., 2007):

1. Degreasing: ultrasonic cleaning at room temperature in acetone bath for $10 \mathrm{~min}$, and then with deionised water at $80^{\circ} \mathrm{C}$ for $10 \mathrm{~min}$ 2. Pre-oxidation: thermal oxidation in a furnace (Lenton, UK) at $950^{\circ} \mathrm{C}$ for different durations: $0,5,10$ and $30 \mathrm{~h}$

The specific mass gain of the coupons as a function of preoxidation time was determined using a mass balance (Ohaus Corporation, USA). The surface topography (namely surface roughness and topography profiles) of the coupons was measured by LPI (Taylor Hobson, UK). The interferometer measured 1000 sampling lengths of $5 \mu \mathrm{m}$ each, thus, covering a total evaluation length of $5 \mathrm{~mm}$. The surface chemical composition of the coupons was determined by XRD using X' Pert Pro diffractometer (Phillips, The Netherlands) having Fe-filtered Co Ka radiation and a power of $45 \mathrm{kV} \times 30 \mathrm{~mA}$. The surface microstructure of the coupons was assessed by using a JEOL 6060 SEM (Oxford Instruments, UK).

\section{Coating of foils by an automatic film applicator}

A $\gamma$-alumina slurry of average diameter $d_{0.5}=4.36 \mu \mathrm{m}$ and solids concentration of $40 \mathrm{wt} \%$ was prepared at a $\mathrm{pH}$ of 4 using ethanoic acid solution (Fischer Scientific, UK). The slurries were deposited onto the Fecralloy ${ }^{\circledR}$ coupons using an automatic film applicator (Sheen Instruments, UK) which provided close control of the traverse coating speed (Adegbite, 2010). The slurries were drawn across the coupons at a traverse speed of $100 \mathrm{mms}^{-1}$ with a wirewound bar of $100 \mu \mathrm{m}$ gap (Figure 1a). The coated coupons were allowed to dry at room temperature, and were then oven dried at $110^{\circ} \mathrm{C}$ for $1 \mathrm{~h}$ and finally calcined at $500^{\circ} \mathrm{C}$ for $1 \mathrm{~h}$ (Jia et al., 2007). The surface view of a product coating obtained by SEM is shown in Figure 1b.

\section{Assessment of coatings}

The coating film loading on the Fecralloy ${ }^{\circledR}$ surface was then calculated by the percentage mass increase of the coupon. To determine coating film adherence, the coated foils were soaked into petroleum ether contained inside a sealed beaker for $30 \mathrm{~min}$, then soaked in an ultrasonic bath $(300 \mathrm{~W}$ and $60 \mathrm{kHz})$ for $1 \mathrm{~h}$ and later dried in an oven at $110^{\circ} \mathrm{C}$ for $2 \mathrm{~h}$ (Valentini et al., 2001). The percentage mass loss was then calculated, meaning that the lower the mass loss the better the coating adherence.

\section{RESULTS AND DISCUSSION}

\section{Pre-oxidation profile}

The pre-oxidation profile shown in Figure 2 represents the specific mass gain by foils as a function of preoxidation time. The increase in the specific mass of the foil with pre-oxidation time arises from the continuous formation of oxide layers on the foil surface. It is shown that the rate of oxide formation, which is the gradient of the curve, was highest at the start of pre-oxidation, and it 


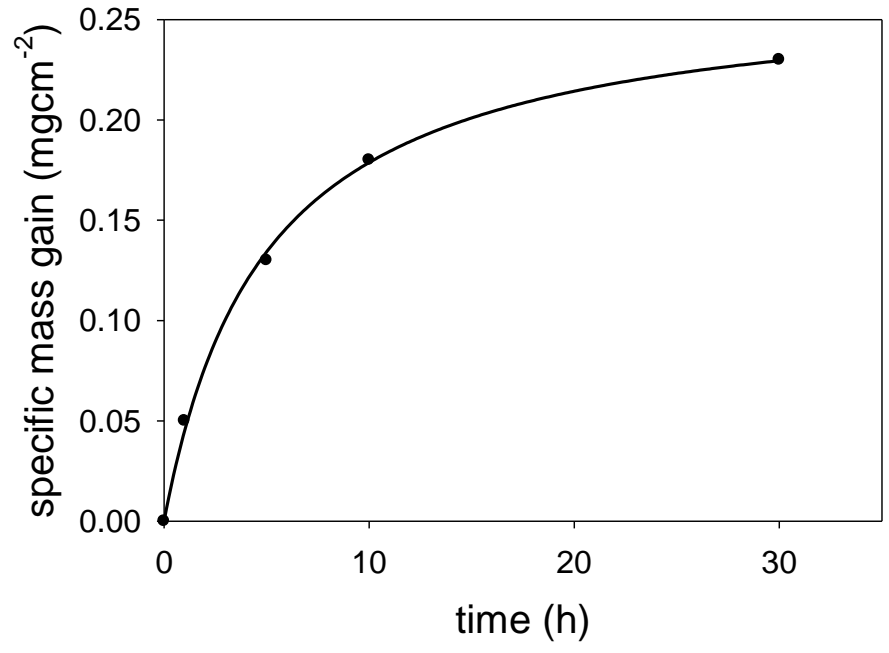

Figure 2. Pre-oxidation profile of Fecralloy ${ }^{\circledR}$ coupons for $0-30 \mathrm{~h}$.

progressively diminished as pre-oxidation continued. A simplified hyperbolic model (Equation 1), derived from a previous study (Pragnell et al., 2005), properly describes the pre-oxidation profile of Fecralloy ${ }^{\circledR}$ for 0 to $30 \mathrm{~h}$.

$$
\Delta \bar{m}=\frac{X t}{Y+t}
$$

where, $\Delta \bar{m}$ is specific mass gain $\left(\mathrm{mgcm}^{-2}\right)$ and $t$ is preoxidation time (h).

Constants $X$ and $Y$ were found to be 0.27 and 5.0 respectively.

\section{Topography characterisation of Fecralloy ${ }^{\circledR}$ coupons by LPI}

The surface topography of the coupons, represented by the $2 \mathrm{D}$ and $3 \mathrm{D}$ roughness parameters and the topography profiles, are shown in Table 1 and Figure 3. The roughness parameters for the untreated coupon were very low because the surface has not been transformed. The roughness parameters increased significantly after $5 \mathrm{~h}$ pre-oxidation, then reached the peak at $10 \mathrm{~h}$ pre-oxidation and later declined upon prolonged preoxidation for $30 \mathrm{~h}$ (Table 1). Clearly, the Fecralloy ${ }^{\circledR}$ coupon pre-oxidised at $950^{\circ} \mathrm{C}$ for $10 \mathrm{~h}$ had the roughest surface; this is supported by the textural profiles shown in Figure 3. Coating film adherence is promoted by rough surfaces which act as glues for coatings because of their irregularities (Jia et al., 2007; Zhao et al., 2003). The profiles shown in Figure 3 also exhibit order in their surface structure due to fabrication patterns, this is particularly evident in the sample shown in Figure 3c which is characterised by deep penetrating grooves.

\section{XRD analysis of Fecralloy ${ }^{\circledR}$ surface}

The XRD patterns in Figure 4 show the surface chemical composition of the coupons pre-oxidised at $950^{\circ} \mathrm{C}$ for $0-$ $30 \mathrm{~h}$. The untreated coupon comprises of a $\mathrm{Fe}(\mathrm{Cr})$ peak and some $\alpha$-alumina peaks, which are present in small amounts (Figure 4a). Pre-oxidation for $5 \mathrm{~h}$ produced substantial amounts of $\alpha$-alumina and a small amount of $\theta$-alumina (Figure 4b). Increased pre-oxidation to $10 \mathrm{~h}$ produced sufficient transformation of $\theta$-alumina into $\alpha$ alumina, as the peaks of the latter are large and conspicuously visible (Figure 4c). Prolonged preoxidation however resulted into formation of a-alumina conglomerates as other alloy elements are spontaneously oxidised; this is characterized by diminishing peaks of $\alpha$-alumina (Figure $4 d$ ). The Fecralloy ${ }^{\circledR}$ surface enrichment by aluminium during pre-treatment is caused by an elemental transport process (Jia et al., 2007; Nicholls and Quadakkers, 2002).

\section{Assessment of Fecralloy ${ }^{\circledR}$ surface microstructure by SEM}

The SEM micrographs displayed in Figure 5 clearly show the distinctions between the surface morphologies of the untreated and pre-oxidised coupons. The untreated coupon (Figure 5a) has a plain surface with no significant microstructure while the pre-oxidised coupons contain $\alpha-$ alumina whiskers (Figures $5 \mathrm{~b}$ to $\mathrm{d}$ ). After $5 \mathrm{~h}$ of preoxidation, there exists trace amounts of $\alpha$-alumina. However, the coupon pre-oxidised for $10 \mathrm{~h}$ was characterized by uniform, conspicuous and randomly oriented $\alpha$ alumina whiskers. It is shown that at this condition the aalumina are properly formed and arranged in a manner which positions them for good adhering capabilities (Avila et al., 2005). The attendant effect of pre-oxidation for up to $30 \mathrm{~h}$ was the formation of non-uniform conglomerates of $\alpha$-alumina.

\section{Coating loading and adherence}

The coating film loading and weight loss from adherence test are shown in Table 2. The values were averaged over 5 measurements with a standard deviation (SD) within $3.5 \%$. Clearly, the duration of pre-oxidation has a major influence on the adherence of the coating film on the Fecralloy ${ }^{\circledR}$ coupons.

The results in Table 2 can be explained in the light of the Fecralloy ${ }^{\circledR}$ surface characterization afore mentioned. For the untreated coupon, the coating loading and adherence were very poor because the foil surface was the least rough and no wettability occurred. The coupons pre-oxidised for 5 and $30 \mathrm{~h}$ showed improved capabilities which are commensurate with their roughness characteristics. The optimal coating loading and adherence were obtained from the coupon with the 
Table 1. Roughness parameters of coupons pre-oxidised at $950^{\circ} \mathrm{C}$ for $0-30 \mathrm{~h}$.

\begin{tabular}{cclcccc}
\hline \multirow{2}{*}{ Roughness parameters } & \multirow{2}{*}{ Type } & \multirow{2}{*}{ Definition } & \multicolumn{4}{c}{ Values $(\boldsymbol{\mu m})$} \\
\cline { 3 - 7 } & & $\mathbf{0} \mathbf{h}$ & $\mathbf{5 h}$ & $\mathbf{1 0} \mathbf{h}$ & $\mathbf{3 0} \mathbf{~}$ \\
\hline $\mathrm{R}_{\mathrm{a}}$ & 2D & arithmetic mean & 0.06 & 0.15 & 0.31 & 0.23 \\
$\mathrm{R}_{\mathrm{q}}$ & 2D & root mean square & 0.08 & 0.17 & 0.36 & 0.20 \\
$\mathrm{~S}_{\mathrm{a}}$ & 3D & arithmetic mean & 0.20 & 0.35 & 0.83 & 0.52 \\
$\mathrm{~S}_{\mathrm{q}}$ & 3D & root mean square & 0.24 & 0.42 & 1.01 & 0.69 \\
\hline
\end{tabular}
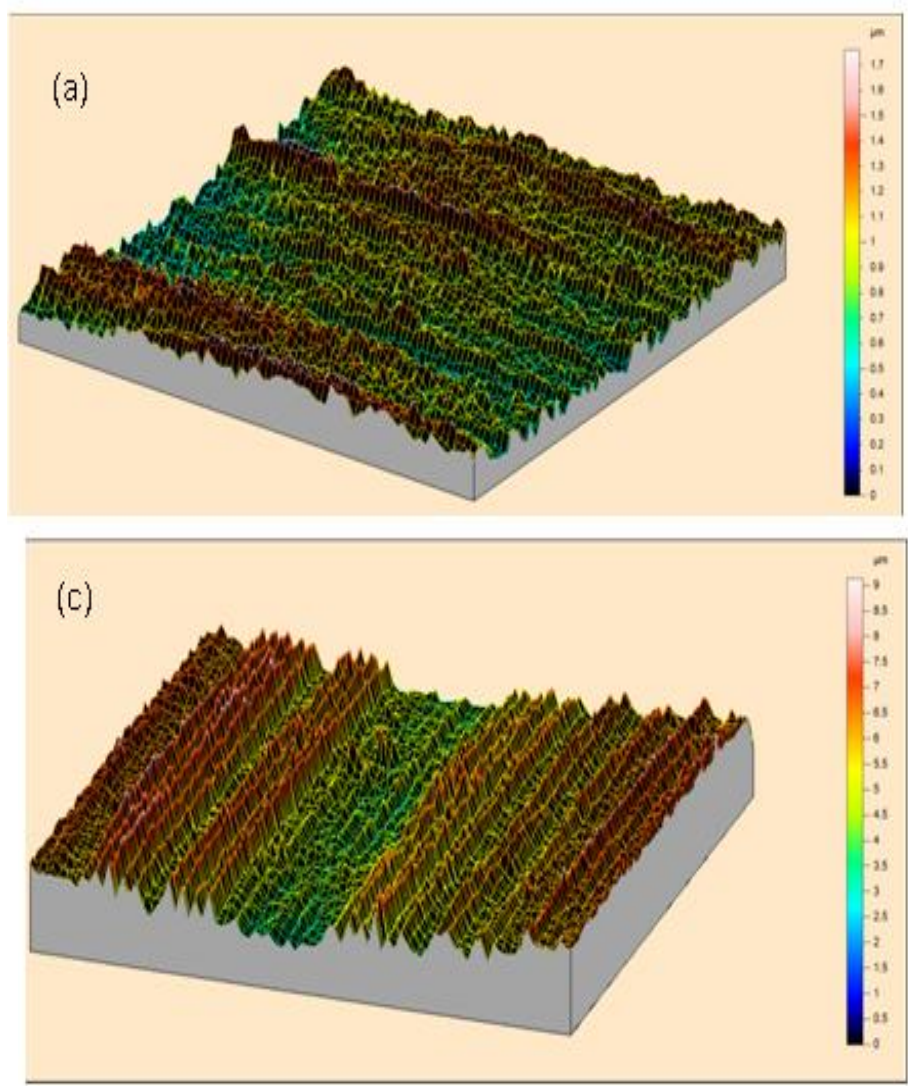
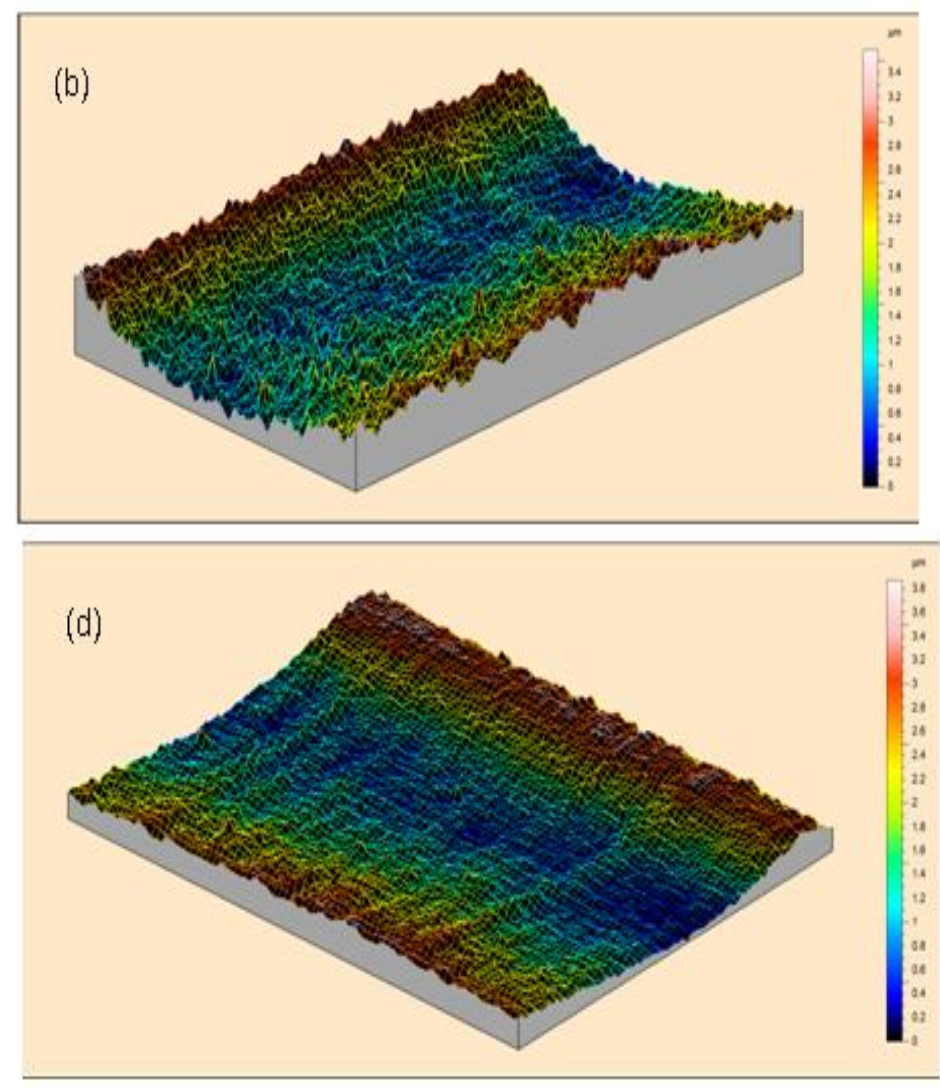

Figure 3. Topography profiles of Fecralloy ${ }^{\circledR}$ coupons pre-oxidised at $950^{\circ} \mathrm{C}$ for (a) $0 \mathrm{~h}$; (b) $5 \mathrm{~h}$; (c) $10 \mathrm{~h}$; and (d) $30 \mathrm{~h}$.

roughest surface i.e. the sample pre-oxidised for $10 \mathrm{~h}$. This is because of the enhanced surface microstructure brought about by the randomly oriented a-alumina whiskers, thereby creating a suitable topography onto which coating film is firmly anchored. The images of the coatings after the adherence test are also given in Figure 6 which revealed the weakened areas where coatings had been lost.

\section{Conclusions}

Fecralloy ${ }^{\circledR}$ foils are materials from which monolith emissions catalysts are made. The Fecralloy ${ }^{\circledR}$ preoxidation conditions have been shown to be central to achieving increased performance, in terms of coating film loading and adherence. A simplified hyperbolic model provided the best fit for specific mass gain by the coupons as a function of pre-oxidation time from $0-30 \mathrm{~h}$. The optimal coating film loading (7.94 mass \%) and adherence (9.90 mass \% loss) were obtained from coupons pre-oxidised at $950^{\circ} \mathrm{C}$ for $10 \mathrm{~h}$, as these conditions produced the optimal surface topography and microstructure.

\section{ACKNOWLEDGEMENT}

This research was supported by the Engineering and Physical Sciences Research Council (EPSRC) in the UK. 

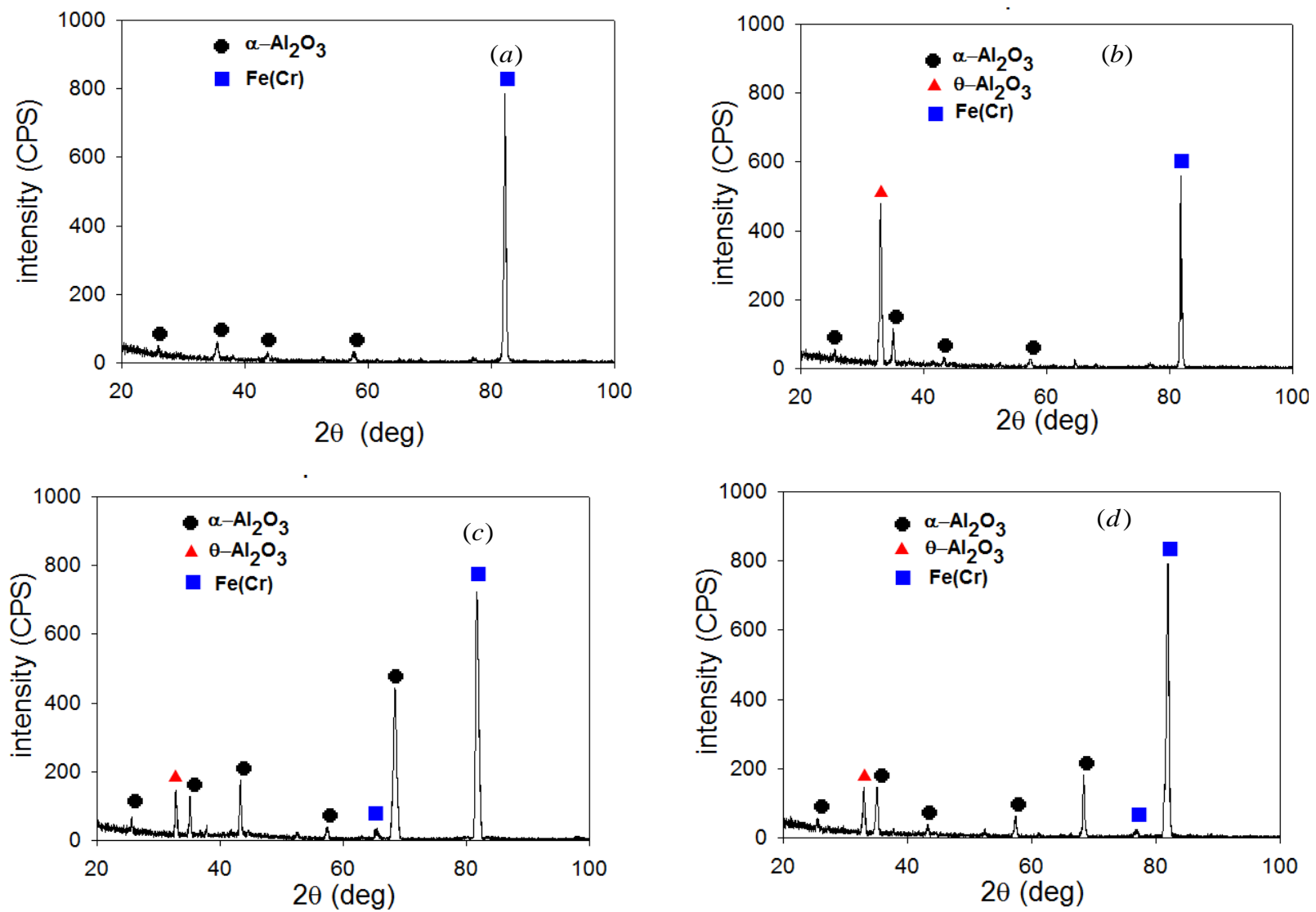

Figure 4. XRD patterns of Fecralloy ${ }^{\circledR}$ coupons pre-oxidised at $950^{\circ} \mathrm{C}$ for (a) $0 \mathrm{~h}$; (b) $5 \mathrm{~h}$; (c) $10 \mathrm{~h}$; and (d) $30 \mathrm{~h}$.
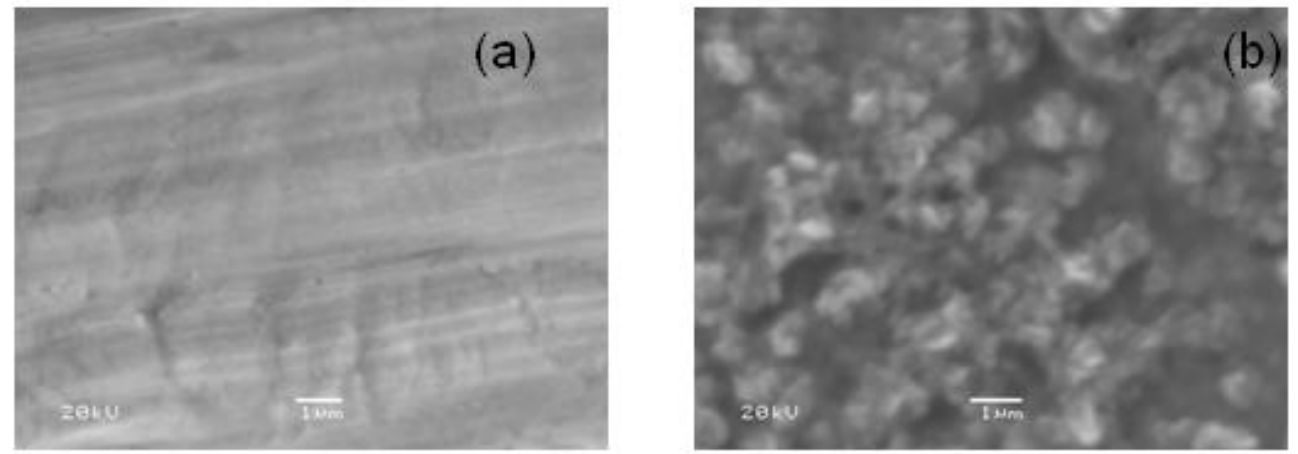

scale:
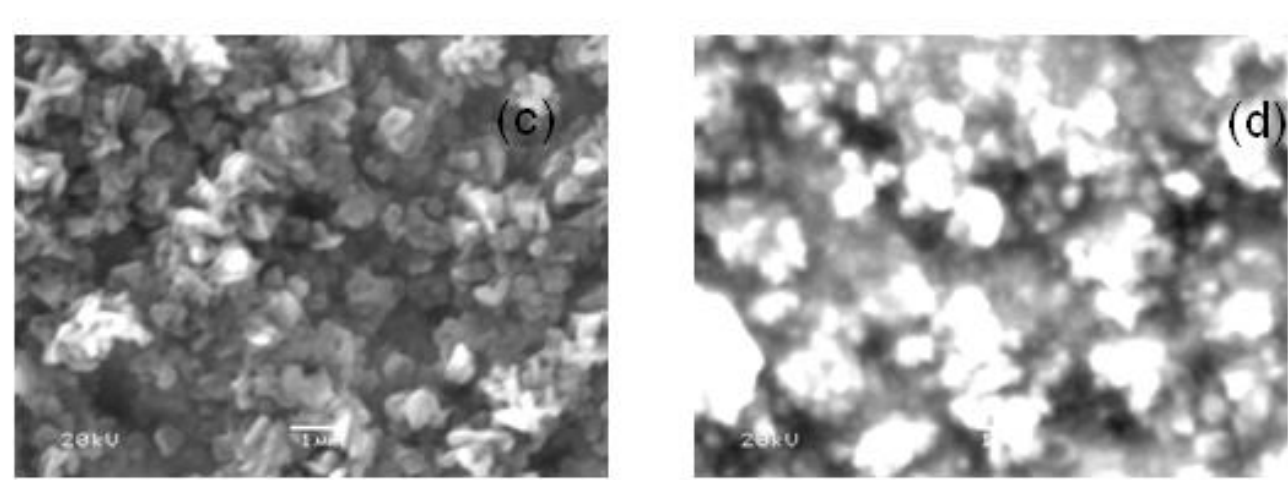

$1 \mu \mathrm{m}$

Figure 5. SEM micrographs of Fecralloy ${ }^{\oplus}$ coupons pre-oxidised at $950^{\circ} \mathrm{C}$ for (a) 0 ; (b) 5 ; (c) 10 and (d) $30 \mathrm{~h}$. 
Table 2. Coating properties for Fecralloy ${ }^{\circledR}$ coupons pre-oxidised at $950^{\circ} \mathrm{C}$ for $0-30 \mathrm{~h}$.

\begin{tabular}{ccc}
\hline Pre-oxidation time (h) & $\begin{array}{c}\text { Coating loading (mass \%) } \\
\text { SD }= \pm 3.1 \% \text { loading }\end{array}$ & $\begin{array}{c}\text { Mass \% loss from adherence test } \\
\text { SD }= \pm 3.5 \% \text { of loss }\end{array}$ \\
\hline 0 & 0.08 & 99.6 \\
5 & 5.19 & 19.4 \\
10 & 7.94 & 9.90 \\
30 & 6.75 & 16.3 \\
\hline
\end{tabular}
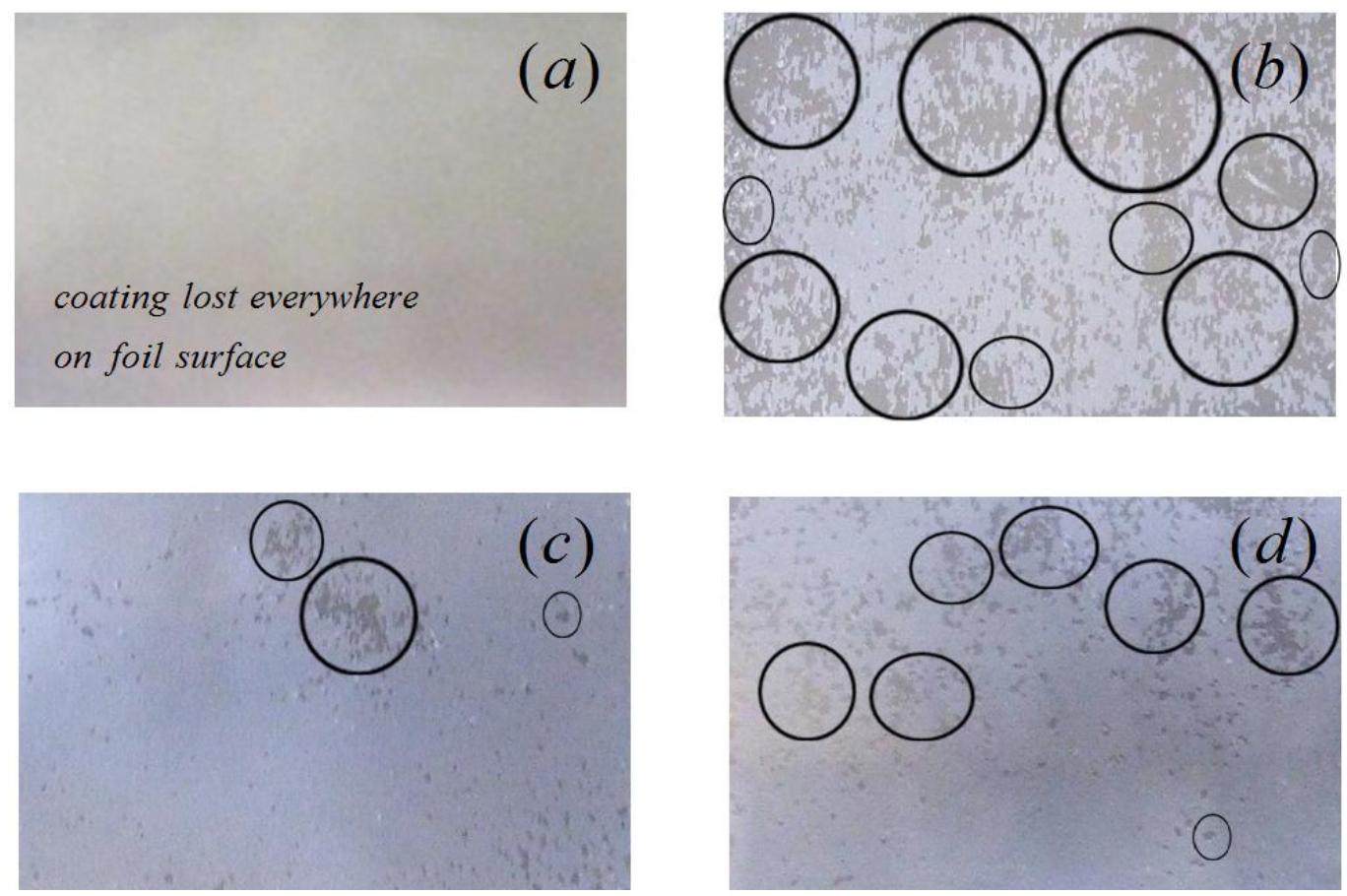

Figure 6. Coatings on Fecralloy ${ }^{\circledR}$ coupons after adherence test (circles indicating some areas of coating loss): (a) 0; (b) 5; (c) 10 and (d) $30 \mathrm{~h}$.

\section{REFERENCES}

Acres GJK, Harrison B (2004). The development of catalysts for emission control from motor vehicles: early research at Johnson Matthey. Topics in Catalysis. 28: 3-11.

Adegbite SA (2010). Coating of catalyst supports: links between slurry characteristics, coating process and final coating quality, Ph.D. Thesis. University of Birmingham. pp. 131-132.

Avila P, Montes M, Miro EE (2005). Monolithic reactors for environmental applications - a review on preparation technologies. Chem. Eng. J., 109: 11-36.

Cybulski A, Moulijn JA (2006) Metal and coated metal catalysts. In: Structured catalysts and reactors. Taylor \& Francis, London. pp. 71 105

Hickman DA, Schmidt LD (1992a). Synthesis gas-formation by direct oxidation of methane over Pt monoliths. J. Catal., 138: 267-282.

Hickman DA, Schmidt,L.D. (1992b). The role of boundary-layer masstransfer in partial oxidation selectivity. J. Catal., 136: 300-308.

Jia LW, Shen MQ, Wang J (2007). Preparation and characterization of dip-coated $\gamma$-alumina based ceramic materials on FeCrAl foils. Surf. Coat. Technol., 201: 7159-7165.
Nicholls JR, Quadakkers WJ (2002). Materials issues relevant to the development of future metal foil automotive catalytic converters. In: Materials aspects in automotive catalytic converters. Bode $\mathrm{H}$ (ed), Wiley-VCH, Weinheim. pp. 31

Pragnell WM, Evans HE, Naumenko D, Quadakkers WJ (2005). Aluminium depletion in FeCrAlY steel during transitional alumina formation. Materials at High Temperatures. 22: 561-566.

Twigg MV (2006). Roles of catalytic oxidation in control of vehicle exhaust emissions. Catalysis Today. 117: 407-418.

Valentini M, Cristiani G, Levi M, Tronconi E, Forzatti P (2001). The deposition of $\gamma$-Al2O3 layers on ceramic and metallic supports for the preparation of structured catalysts. Catalysis Today. 69: 307-314.

Zhao S, Zhang JZ, Weng D, Wu XD (2003). A method to form welladhered $\gamma$-Al2O3 layers on FeCrAl metallic supports. Surf. Coat. Technol., 167: 97-105. 